\title{
Potential geoheritage assessment; Dereiçi travertines, Başkale, Van (east anatolian Turkey)
}

\author{
Çetin Yeşilova
}

Van Yüzüncü Y1l University, Faculty of Engineering, Department of Geological Engineering, Van 65000, Turkey, cetinyesilova@gmail.com, ORCID: 0000-0002-8884-0842

\begin{abstract}
A B S T R A C T
Dereiçi travertines famous for their Pamukkale-like conveyors are located to the south of the Başkale district of Van. The travertines are located after the 30th km of Başkale - Hakkâri highway and after $12 \mathrm{~km}$ by the road separating to the west. In this study, the morphological analyzes of travertines bearing geological heritages and their evaluation as "geo-tourism" were investigated. The oldest travertines in the region are the Layer-Type Traverteners at the base. On the Layer Type Travertines are the shear cracks developed in the K 10 B and K $40 \mathrm{D}$ directions due to regional compressions and the Ridge Type Travertines formed by the waters from this crack. Finally, the waters draining down the slope from the cracks opening in the northeastern slope of the Ridge Type Travertines form the old and current Terrace Type Travertines.There are also small-sized Cave Type Travertines in the void spaces of various sizes developed in back-type travertines. When considered in potential of geoheritage, the region draws attention with two Ridge Type Travertines, a traverten bridge, some non-active terraced travertine, and a waterfall along a shear crack.In addition, the appearance of the natural walls formed by the downwind water due to the inclination of the Ridge Type Travertines along the northeast patch is also worth seeing. Dereiçi Travertines is one of the most important regions to be evaluated and protected from the perspective of geoheritage. However, these geological assets have not been found to be interesting, but at the same time, they have recently become the targets of the managerships looking for marble industry. Moreover, because of the increasingly decreasing hydrothermal waters coming out of the cracks, some of these terraces are dried up and some of them are coming to the stage of drying.The measures to be taken in order to continue natural formation are discussed in this article.
\end{abstract}

ARTICLE INFO

\section{Research article}

Received: 31.03.2021

Accepted: 17.05.2021

Keywords:

Dereiçi,

travertine,

geoheritage,

Başkale,

Van

\section{Introduction}

Geological units that record all the evolution of the time they were formed are called geological sites (geocytes) [1]. These geosites can be a rock sequence, fossil assemblages, structure, texture or a specific region [2, 3]. Geosites that facing the threat of extinction are called "geological heritage" [2, 3]. Special nature protection zones that contain the same or different types of geological heritage are called geoparks [1]. Geoparks have an important place and tourism potential in this sense.

There are many studies on the geoparks in Turkey [3-8]. In addition, important studies have been carried out for the recognition and protection of geoparks [9-11]. In recent years, Çiftçi and Güngör have worked to standardize Geoparks and inventory studied in these areas [12-15].
In this study, as suggested by Çiftçi and Güngör, it is aimed to contribute to the preparation of the "geotourism oriented" geological heritage inventory of the Dereiçi (Başkale) region [13]. De Lima et al. (2010) stated that in order to present such inventories, subject, scope, scale and purpose of use should be determined. Such a study can only be carried out within the scope of an envisaged geopark study [16].Visual features come to the fore in geomorphological elements. These visual features are partly dependent on subjective evaluations. However, such structures also have a scientific value as representing any period of geological history. As a suggested in Çiftçi and Güngör, geosites within the scope of a geopark are classified according to their scientific and visual value, get a certain score and their weight in the geopark is controlled in this way [13]. 


\section{Regional geology}

Dereiçi Village is located approximately $23 \mathrm{~km}$ southeast of Başkale district of Van (Fig. 1). The basement in the study area are represented by Paleozoic - Mesozoic metamorphic rocks belonging to the Bitlis Massif (Fig. 1). Bitlis Massif is composed of metamorphic rocks in the P-T conditions ranging from low to high, it is one of Turkey's largest and most important massifs. According to many researchers [17-20], this massif is divided into two different main units as Lower Metamorphites and Upper Metamorphites. Upper Cretaceous aged Yüksekova Complex unconformably overlies Bitlis metamorphics. This complex was firstly described by Perinçek [21].

The Yüksekova Complex is the dominant unit in the study area and has a wide distribution in the regions of Ylan Village, Meşeli Village, Boğaz Hill and Billurik River. This complex, represented by very different rock assemblages in Hakkari and its vicinity, was studied under the name of three different rock groups in the study area. These are granitic rocks, dioritic rocks and aplitic veins cutting these rocks. The
Durankaya Complex unconformably overlies this complex and outcrops over a large area in the study area. The Durankaya Complex was first described by Perinçek [22]. The type section of the unit is seen around Durankaya Village, 22 $\mathrm{km}$ southwest of Hakkari Province, and is represented by shale, sandstone and limestone. It also contains serpentinite, gabbro, amphibolite and marble levels in places. Shales are extremely deformed and gray in color. Limestones with a thickness of $700 \mathrm{~m}$ are claret red and red in color and in places in the form of clayey limestone. The unit was deposited in slope-deep sea environment [22]. The travertines and current alluviums, which are related to NE-SW trending strike-slip faults, formed as a result of tectonic movements in the region, constitute the youngest units in the study area (Fig. 1).

The aim of this study is to determine the geomorphological geoheritage elements of the travertine formations [23], which were partially examined and defined before, to evaluate them in terms of geotourism and to discuss the conservation conditions.

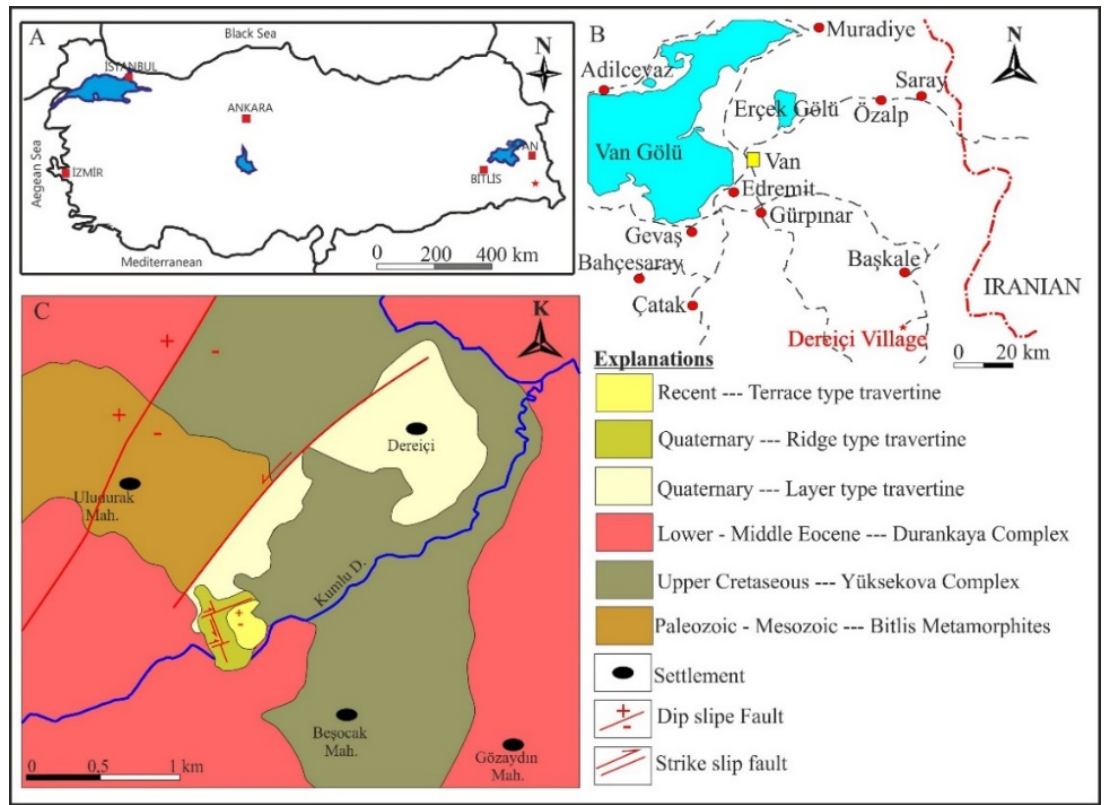

Figure 1. Of the study area, Turkey (A) and in Van Province (B) map showing the location. C, Geological map of the study area. The red star shows the location of the travertines.

\section{Results}

According to the studies conducted on the travertines in the region in previous years [23], there are three different geomorphological processes and three different travertine formation:

1. "Layer Type Travertines", most of which are formed by crystalline crustal facies,
2. An mode-I crack and "Ridge Type Travertines" developed due to this crack.

3. "Terrace Type Travertines", which developed due to mode-I cracks and still continue to form(Fig. 2). These formations will be introduced sequentially from south to north. 


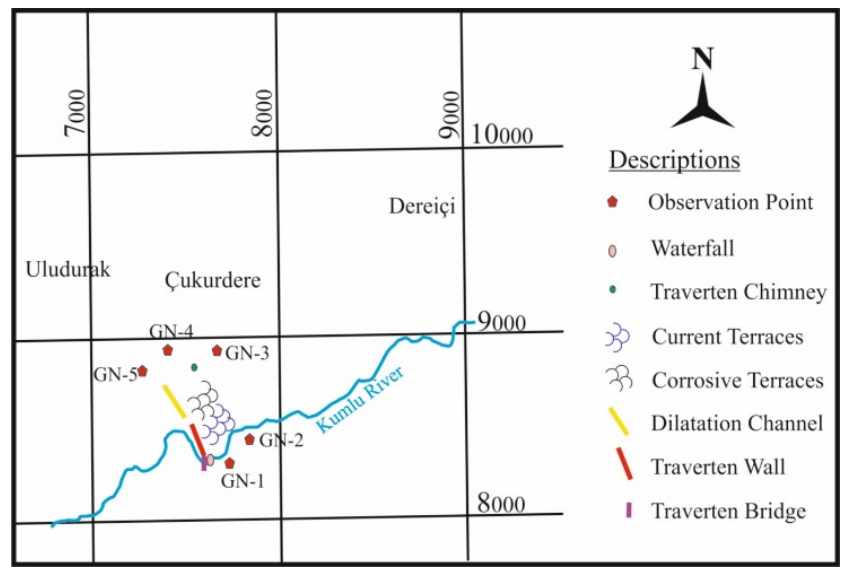

Figure 2. Potential geoheritage elements and locations in the study area.

\subsection{Mode-I crack, walking channel and travertine wall}

It is located on a slope at the southernmost point of Dereiçi Travertines and consists of "ridge type" travertines formed by the waters flowing through a crack opened in the $\mathrm{N} 40^{\circ} \mathrm{E}$ direction (Fig. 3A). The southeastern parts of the crack opened up in time and turned into a channel with a width of 47-68 cm and a depth of $40-80 \mathrm{~cm}$ (Fig. 3B). On the northeast slope of the travertines, the waters flowing along the sloping surface formed a steep wall on this slope (Fig. 3C). The wall is $80 \mathrm{~m}$ long and has a height of 3 to $5 \mathrm{~m}$ and a width of 1.2 to $3.5 \mathrm{~m}$. Travertines consist of light brown - beige colored layers varying between $0.7-10 \mathrm{~cm}$. The fact that they are generally composed of gas bubble and crystalline crustal facies indicates that these travertines are precipitated by gases-rich hot waters [24].

\subsection{Travertine chimney}

It is a small fracture that develops in the area and a travertine formation that grows upward through the fracture. It is located in front of the slope to the north of the walking channel (Fig. 2). Its thickness is between 1.3 and $3 \mathrm{~m}$, its height is $2.7 \mathrm{~m}$ and its width is around $2 \mathrm{~m}$. This formation stands as if it witnessed history. It consists of cream beige crystalline crust facies (Fig.3D).

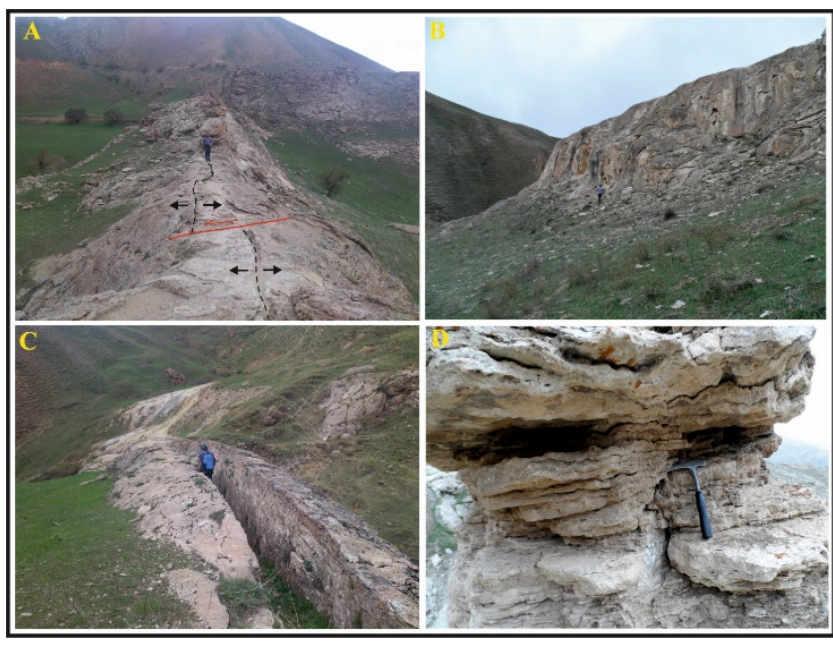

Figure 3. A. Mode-I crack forming on the ridge type travertines, $B$. Channel structure formed in ridge type travertines, $C$. Wall formed in back type travertines, $D$. Travertine chimney.

\subsection{Travertine bridge}

It is a rare beautiful travertine bridge formed by the opening crack in the $\mathrm{N} 40^{\circ} \mathrm{E}$ direction over the existing stream in the area (Fig. 2, 4A). The travertine bridge was formed as a result of the carving and giving way of the current cracks in the ridge type travertine, which blocks the front of the river. The bridge is $5 \mathrm{~m}$ high, $3.3 \mathrm{~m}$ wide and $1.5-2.5 \mathrm{~m}$ thick.

\subsection{Waterfall}

The travertine waterfall, which was formed as a result of the discharge of the waters coming out of this bridge along a steep slope in the north of the travertine bridge, presents a natural beauty in itself (Fig. 4B). The waterfall has 3 steps. Its total height is $6 \mathrm{~m}$, and its width is around $3 \mathrm{~m}$. Although the amount of water in the waterfall increases in rainy seasons, there is a continuous flow.

\subsection{Travertine Pool.}

Terrace type travertines formed by old and current water outlets form these pools (Fig. 4C D). These draw attention with their similarities to Pamukkale Travertines. Pisolitic type travertine formation is observed in the terrace pools of travertines. These waters, which are concentrated in volatile components, form "crystalline crust" on the terrace edges and "gas-bubble" and "paper thin-raft type" travertines in the travertine pools. More than $60 \%$ of the terrace type travertines dryed out as a result of the decrease in the water forming them and the change of direction (Fig. 4E). If no action is taken, in the future, all of these travertines will start to dry and go through the wear process. The pools range from a few $\mathrm{cm}$ wide to 2 - $3 \mathrm{~m}$ wide. The deepest pool is around $50 \mathrm{~cm}$. At the exit of the waters forming the current pools, bad-smelling gases also exit. From the discolorations on the edges of the travertine pools, it is understood that the gases released are rich in sulfur (Fig. 4F). 


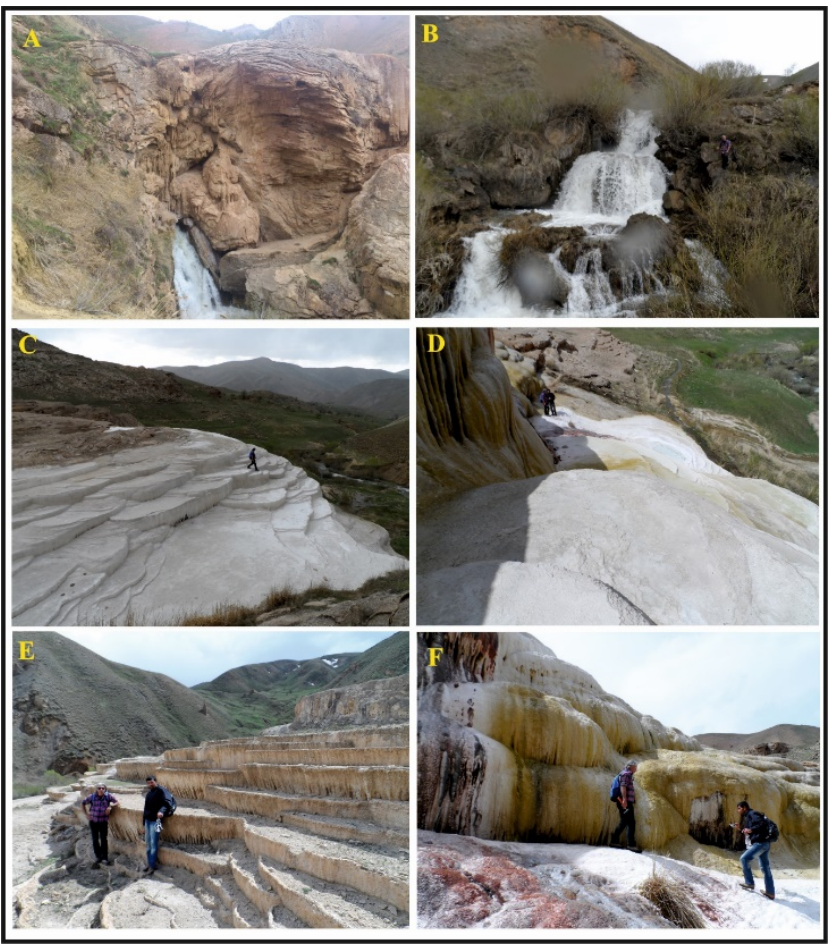

Figure 4. A. Travertine bridge, B. Waterfall structure formed on steep slopes, C. Terrace of travertine, D. Travertine pool, E. The travertine terraces that have begun to wear out, F. Discoloration that develops depending on the amount of sulfur in the water.

\section{Conclusion}

In studies conducted on travertines, crystalline crust, paperthin raft type, gas buble, shurb type and pisolitic travertine facies were found. Both their morphology and facies characteristics show that Dereiçi Travertines were formed by the flow of hydrothermal waters rich in volatile components down the slope to the surface along a shear crack..

The travertines in the region have a great potential in terms of geotourism. However, both short-term and long-term studies need to be done.

In the short term; Marble cutting and excavation operations have been identified by some investors in the region (Fig. 5A). For this reason, in order to protect and maintain the region, constant meetings have been held with the Governorship, Relevant municipalities and non-governmental organizations. In this context, the Law No. 2863, Article 13 / A of the Decree No. 644 (LAW; 2013) [25]; It has been taken under protection within the scope of the "Regulation on Procedures and Principles Regarding the Determination, Registration and Approval of Protected Areas" (LAW; 2012) [26], published in the Official Gazette dated 19.07.2012 and numbered 28358 (Official Gazette dated 04.03.2020 and numbered 31058, decision number: 2195). However, in addition to taking the area under protection, there should be restrictions on daily visitors' activities.

Only 40\% of the Dereiçi Travertines are still up-to-date (Fig. 5B). The gradually decreasing water exit in the region will cause the travertines to dry and then erosion. With the detailed geological, hydrogeological and geophysical studies to be done, the chemistry, depth, reserve etc. of the underground water. must be determined. By bringing these underground waters to the surface, the regeneration of travertines can be continued without disturbing the naturalness of the travertines.

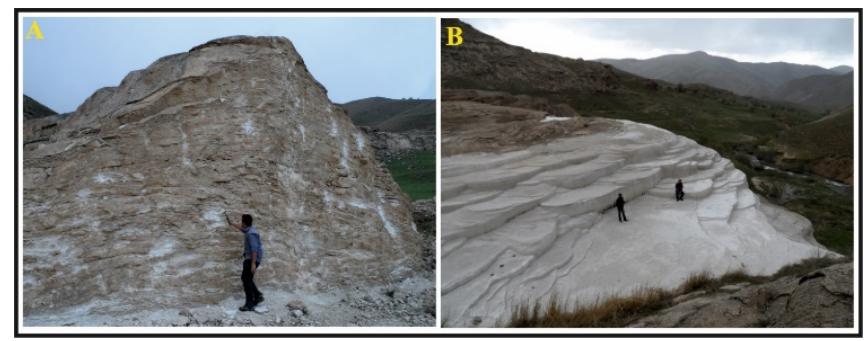

Figure 5. A. The damages caused by the marble operators to the tarvertines and natural structure in the region, $B$. Terrace type travertines that are still being formed.

Access to the travertines is via a $20 \mathrm{~km}$ stabilized road from the main road. This road is under heavy snow cover most of the year. Therefore, it is recommended that this road be improved and asphalted as soon as possible.

In the long term; These are divided into two as sociological and tourism studies. Sociological studies of the area where the travertines are located should be conducted by sociologists who are experts in their field, to raise awareness about the travertines in the region, and to organize meetings with local administrations and investors in the region about the geotourism potential of travertines. Studies should be carried out to reveal the importance and added value potential of the said travertines for tourism agencies operating in the national and Lake Van Basin, with studies to be organized by tourism professionals who are experts in their fields. In addition, even if it is simple, the preparation of the signs that introduce both the geological and geomorphological features of these travertines will contribute to the awareness to be created on the local people.

In the Lake Van Basin and its eastern part, dozens of geological heritage elements that have both scientific value and touristic potential can be counted at once, but unfortunately this has no practical benefit. With the detailed studies to be done, the inventories of the geological and cultural heritage elements in the region should be prepared in accordance with the "geological heritage accreditation" stated by Çiftçi and Güngör (2017b). These inventories, supported by scientific data, can only be contributed to the sustainable 
development of the people of the region and country tourism when they are owned by the local governments in the region.

\section{Acknowledgements.}

This study was carried out within the scope of Yüzüncü Y1l University Scientific Research Projects project no "2014MiM-B074". I would like to thank Cahit Helvac1, Yahya Çiftçi, Mustafa Açlan, Yıldırım Güngör and Pelin Güngör Yeşilova for their contribution in the preparation of the article and field studies.

\section{References}

[1]. Kazancı N., Özgen Erdem N., Erturaç MK., "Kültürel Jeoloji ve Jeolojik Miras; Yerbilimlerinin Yeni Aç1lımları", Türkiye Jeoloji Bülteni, 60/1 (2017), 1-16.

[2]. ProGeo Group., "A first attemt at a geosites frameworkfor Europe -an lUGS initiative to support recognition of World heritage and European geodiversity”. Geologica Balcanica 28, (1998), 5-32.

[3]. Kazancı N., "Dünyada ve Türkiye'de Jeosit-JeoparkJeomiras Olgusuna Yaklaşımlar". KızılcahamamÇamlıdere Jeopark ve Jeoturizm Projesi Raporu", (2010a) 76p, Ankara.

[4]. Kazancı N., "Milli Parklarda Jeolojik Miras 1, Soğuksu Milli Parkı (Kızılcahamam-Ankara)”, Çevre, Atmosfer, Yer ve Deniz Bilimleri Araştırma Grubu, (2007) 61p, Ankara.

[5]. Kazanc1 N., "Jeolojik Koruma (Kavram ve Terimler)", Jemirko ve TMMOB Jeoloji Mühendisleri Odası Yayınları, (2010b) 60p, Ankara.

[6]. Kazancı N. Şaroğlu, F., "Türkiye Jeositleri Çatı Listesi”. 62. Türkiye Jeoloji Kurultayı (13-17 Nisan 2009) Bildiri Özleri Kitabı-I, Jeoloji Mühendisleri Odası, Ankara, (2009) 266-267.

[7]. Gürler G., Timur E., “Jeoparkların Koruma Kullanım Yöntemlerinin Belirlenmesi; Karapınar Potansiyel Jeopark Alanı İçin Bir Değerlendirme, Türkiye”. Proceedings of The Second International Symposium on Development Within Geoparks Environmental Protection and Education, Lushan, Jiangxi Province, China, 12-15 June, (2007).

[8]. Koçan N., "Ekoturizm ve Sürdürülebilir Kalkınma: Kızılcahamam-Çamlıdere (Ankara) Jeopark ve Jeoturizm Projesi”. Karadeniz Fen Bilimleri Dergisi, 2/6, (2012a) 69-82, Trabzon.
[9]. Gürler M., "Doğal koruma alanlarının belirlenmesi ve planlanmasında jeoloji. JMO Semineri; Aynı yazı ve yazar”: Birlik Haberleri, Sh. (1997) 46-48.

[10]. Gürler M., "Ekolojik planlamada jeolojik oluşumlar için öneri bir sınıflama modeli”. TMMOB Birlik Haberleri, Mayıs-Haziran Sayısı, (1999), Ankara.

[11]. Gürler, M., “Anıt nitelikli jeolojik oluşumlar ve koruma çalışmaları". JMO Mavi Gezegen Popüler Bilim Dergisi, S. 4, (2001) 10-11, Ankara.

[12]. Çiftçi Y., Güngör Y., “Jeosit Tanımlama ve Jeopark Düzenleme Standartları Üzerine Bir Çalışma”, 67. TJK. Bildiri özleri kitabı, (2014) p. 422, Ankara.

[13]. Çiftçi Y., Güngör Y., “Jeopark Projeleri Kapsamındaki Doğal ve Kültürel Miras Unsurları İçin Standart Gösterim”. Maden Tetkik ve Arama Dergisi, 153, (2016) 223-238.

[14]. Çiftçi Y., Güngör Y., “Jeolojik Miras Envanteri Hazırlamada Terminoloji, Yöntem, Kurumsal Sahiplenme ve Eşgüdüm”. 70. Türkiye Jeoloji Kurultayı Bildiri Özleri, (2017a), p. 620 - 621, 10-14 Nisan 2017, Ankara

[15]. Çiftçi Y., Güngör Y., “Dünya'da ve Türkiye'de Jeolojik Miras Envanteri Hazırlama ve Jeokoruma Çalışmaları: Akreditasyon, Ulusal Kodlama Sistemi ve Etkileşimli Veri Tabanı Önerisi”. 70. Türkiye Jeoloji Kurultayı Bildiri Özleri, (2017b), p. 252 - 253, 10-14 Nisan 2017, Ankara

[16]. De Lima F.F.,Brilha J.B., Salamuni E., "Inventorying Geological Heritage in large territories: a methodological proposal applied to Brazil”. Geoheritage, 2, (2010) 91-99.

[17]. Yılmaz O.,. “Cacas bölgesi (Bitlis Masifi) kayaçlarının petrografik ve stratigrafik incelenmesi”. Türkiye Jeoloji Kurumu Bülteni, 18/1, (1975) 33-41.

[18]. Tolluoğlu A. Ü., "Mutki (Bitlis) yöresi metamorfiklerinin petrografisi/petrolojisi”. Yüksek Mühendislik Tezi, Hacettepe Üniversitesi, (1981), 86 p. Ankara (yayımlanmamış).

[19]. Şengün M., “Tatvan güneyinin (Bitlis masifi) jeolojik/ petrografik incelenmesi”: Doktora tezi, (1984). 157p. (yayımlanmamış).

[20]. Göncüoğlu, M. C. ve Turhan, N., "Bitlis Metamorfik kuşağ1 orta bölümünün temel jeolojisi”. MTA Rapor No. (1985), 7707 (yayımlanmamış). 
[21]. Perinçek D., “The Geology of Hazro-Korudağ-ÇüngüşMaden-Ergani-Elazığ-Malatya area”: Guide Book, TJK yayını, (1979), Ankara

[22]. Perinçek D., "Hakkari ili ve dolayının stratigrafisi, GDA Türkiye”: TPJD Bülteni, 2/1, (1990), 21-68.

[23]. Yeşilova Ç., Açlan, M., Güngör Yeşilova, P., "Van Gölü Çevresindeki Travertenlerin Jeoturizm Açısından Değerlendirilmesi", Doğu Anadolu Jeoloji Sempozyumu , (2015), 252 - 253 p , Van, Türkiye , 07 12 Eylül 2015

[24]. Ayaz E., "Travertenlerde Gözlenen Morfolojik Yapılar ve Tabiat Varlığı Olarak Önemleri”. Cumhuriyet
Üniversitesi Mühendislik Fakültesi Dergisi, Seri AYerbilimleri 19/2, (2002), 123-134, Aralık 2002

[25]. ÇŞB., "Korunan Alanların Tespit, Tescil ve Onayına İlişkin Usul ve Esaslara Dair Yönetmelik”, (2012), Çevre ve Şehircilik Bakanlığı, Tabiat Varlıklarını Koruma Genel Müdürlüğü.

[26]. ÇŞB., “Doğal Sit Alanlarının Değerlendirilmesine İlişkin Yönetmelik", (2013), Çevre ve Şehircilik Bakanlığı, Tabiat Varlıklarını Koruma Genel Müdürlüğ̈̈. 